\title{
REPRODUCTIVE AND PRODUCTIVE EFFICIENCY OF BARKI EWES FED ON NIGELLA SATIVA MEAL AS A SOURCE OF RATION PROTEIN
}

\author{
E.B. Abdalla ${ }^{1}$; A.S. El-Hawy ${ }^{2}$; H.A. Gawish ${ }^{2}$ and Effat M. Madany ${ }^{2}$ \\ ${ }^{1}$ Animal Production Department, Faculty of Agriculture, Ain Shams University, Cairo, Egypt. \\ ${ }^{2}$ Animal Physiology Department, Desert Research Center, Cairo, Egypt.
}

(Received 20/6/2014, accepted 30/7/2015)

\section{SUMMARY}

$\mathrm{S}$ ixty adult Barki ewes (2.0-3.0 years old and $38.89 \pm 1.02 \mathrm{~kg}$ average body weight) were used to investigate the effect of feeding Nigella sativa meal as an alternative source of protein on the reproductive and productive performance of Barki ewes. Animals were randomly assigned into equal three groups (20 each). The first group (G1) served as control and fed the basal diet contain $20 \%$ cotton seed meal and 6\% soya bean meal as a source of ration protein, while the second group (G2) fed diet contained $13.5 \%$ of Nigella sativa meal (NSM) and $8 \%$ soya bean meal as a source of ration protein. The Third group (G3) fed diet contained $25 \%$ of NSM as a source of ration protein. All groups were offered berssem (Trifolium alexandrnum) hay ad libitum, and rations were adjusted monthly to cover their requirements during their different physiological status. Reproductive traits in terms of conception and lambing rates, abortion and stillbirth rates, number of lambs born alive and weaned and mortality rate from birth to weaning were measured during this study. Birth and weaning weights as well as body weight changes of ewes recorded during different physiological stages. Milk yield and composition were also determined. Results indicated that conception and lambing rates were insignificantly higher in G1 and G2 compared with G3. While number of lambs born alive was higher in G2 and G3 than control group (19 and 18 Vs. 17 lambs for G2, G3 and G1 respectively). Birth and weaning weights were significantly higher in G3 then G2 compared with control group. G3 recorded higher milk production during lactation period $(627.29 \mathrm{ml} / \mathrm{h} / \mathrm{d})$ then G2 $(601.33 \mathrm{ml} / \mathrm{h} / \mathrm{d})$ while control group recorded the lowest value $(587.33 \mathrm{ml} / \mathrm{h} / \mathrm{d})$. Progesterone profile in the three experimental groups was found to follow the normal pattern reported in the literature. Progesterone levels insignificantly increased in control group than other two groups during pregnancy, especially during late pregnancy and decreased to the basal values after parturition. In conclusion, we can use NSM as an alternative source of ration protein to improve reproduction and production efficiency of Barki ewes under arid conditions of North Western Coast of Egypt.

Keywords: Reproductive and productive efficiency, Barki ewes, Nigella sativa meal.

\section{INTRODUCTION}

In Egypt, there are about 5.6 and 4.13 million heads of sheep and goats, respectively. Sheep and goats serve as investment and insurance due to high fertility, short generation interval and adaptation to harsh environment (Tsedeke, 2007 and Khalil et al., 2013). The productivity of sheep and goats was reported to be low due to a number of factors as feed shortage either in quality or quantity and health constraints (Tsedeke, 2007). The lake of sufficient feed to meet the nutritional requirements of existing animal population is one of the most critical problems of animal production in Egypt. Therefore, many attempts have been made for using feed additives or agriculture byproducts (Ismaiel et al., 2010) that are added to animal feed to improve their nutritive value, increasing growth rate and better feed conversion efficiency (Pluske, 2013).

The antioxidant activity is high in medicinal plants and antioxidants play an important role in inhibiting and scavenging radicals which providing protection to humans against infectious and degenerative diseases (Anwar et al., 2004). Herbs could be expected to serve as feed additives due to their suitability and performance, reduced risk of toxicity and minimum health hazards (Devegowda, 1996). The World Health Organization (WHO) encourages using medical herbs to minimize the use of chemicals through the global trend to go back to natural nutrients (Mohamed et al., 2003). Nigella sativa contains over 100 valuable components, so it is a significant source of essential fatty acids, proteins, carbohydrates, vitamins A, B1, B2, C and niacin as well as minerals and carotene. Nutritional 
composition of Nigella sativa meal is protein $21 \%$, carbohydrates $35 \%$ and fats $35-38 \%$. In addition, Nigella sativa reduces the toxicity of cisplatin that induced fall in leucocytes count, hemoglobin levels and mean osmotic fragility of erythrocytes. (Nair et al., 1991).

Nigella sativa is rich in nutritional values like mono-saccharides and non-starch polysaccharide component which is a useful source of dietary fiber and also rich in fatty acids, particularly, the unsaturated and essential fatty acids which cannot be manufactured by the body alone and therefore animals acquire these from food. Fifteen amino acids make up the protein content of the Nigella sativa, including the nine essential amino acids (Ferdous et al., 1992). The black seed is also a source of calcium, iron, sodium and potassium as well as most of trace elements which act as essential cofactors in various enzyme functions (Chevallier, 1996).

Many authors studied the effect of Nigella sativa seeds supplementation or its products as oil or meal on the blood metabolites, reproductive and productive performance of different animals (Sanad, 2010, Randa, 2007 and El-Gaafarawy et al., 2003).

Zanouny et al. (2003) showed that the supplementation of male lambs with Nigella sativa by a level of $100 \mathrm{gm} / \mathrm{kg}$ had positive effects on blood metabolites and reproductive performance. However, there were wide variations in the literature concerning the suitable level of Nigella sativa meal, which can be supplemented in the diet of animals. Therefore, the objective of this study was to evaluate the effect of Nigella sativa meal as a source of ration protein on reproductive and productive performance of Barki ewes and their lambs under arid conditions of North Western Coast of Egypt.

\section{MATERIALS AND METHODS}

This study was carried out during the period from April 2014 to March 2015 at the Animal Production Unit in the Sustainable Development Center for Matrouh Resources, Matrouh Governorate, belongs to the Desert Research Center in the North Western Coast of Egypt.

This study aimed to investigate the impact of Nigella Sativa meal (NSM) as a source of ration protein on the reproductive and productive performance of Barki ewes and their lambs under arid conditions of North Western Coast of Egypt.

\section{Animals and Management:}

Sixty adult Barki ewes (2.0-3.0) years old and 38.89 $\pm 1.02 \mathrm{~kg}$ average body weight) were assigned randomly into three equal groups (20 each). The first group (G1) served as control and fed the basal diet contained $20 \%$ cotton seed meal and $6 \%$ soya bean meal as a source of protein, while the second group (G2) fed diet contained $13 \%$ of NSM and $8 \%$ soya bean meal as a source of main ration protein. The third group (G3) fed diet contained 25\% of NSM as a source of main ration protein as shown in Table (1).

Table (1): Ingredients percentage of different experimental rations.

\begin{tabular}{lccc}
\hline Item & Diet 1 & Diet 2 & Diet 3 \\
\hline Yellow corn & 50 & 54 & 53 \\
Wheat bran & 20.5 & 21.5 & 18.5 \\
Cotton seed meal & 20 & 0 & 0 \\
Soya bean & 6 & 8 & 0 \\
Nigella sativa & 0 & 13 & 25 \\
Limestone & 1.5 & 1.5 & 1.5 \\
Mineral mixture & 1 & 1 & 1 \\
Sodium chloride & 1 & 1 & 1 \\
\hline
\end{tabular}

All groups were offered berssem (Trifolium alexandrnum) hay ad libitum, and rations were adjusted monthly to cover their requirements during their different physiological status according to Kearl (1982). Animals were fed three weeks as a transitional period, on the tested rations before the start of the experiment work. Fresh water was available to all groups daily. Animal were kept in semi-open pens roofed with wood, and were clinically healthy and free from internal and external parasites. 
Mating season started in May 2014 and lasted for 34 days (equal to 2 estrous cycles). Five fertile rams were allowed to rotate among different ewes groups to avoid ram/group confounding effect. Rams were fed the control concentrate ration and removed from the ewes groups at early morning before offering rations.

Once lambing took place, the born lambs were ear tagged and weighed to record their birth weight and then biweekly till weaning that took place at 3 months then weaning weight was recorded and adjusted for 90 days.

\section{Milk samples:}

Milk samples $(50 \mathrm{ml})$ were taken biweekly from 5 animals within the respective groups during 12 weeks lactation period, in plastic bags and kept under $-20{ }^{0} \mathrm{C}$ for further analysis. Milk yield was determined biweekly from lambing up to 12 weeks lactation period, representing early (up to the $4^{\text {th }}$ week), mid (up to the $8^{\text {th }}$ week) and late lactation periods (up to the $12^{\text {th }}$ week), through the complete hand milking of the udder after fasting lambs for 12 hours for two consecutive days once at night and the next at morning to cover 24 hours.

Chemical composition of milk in terms of fat, protein, lactose, total solids and solids not fat was determined using milk scan (Bently-Belguim).

\section{Blood samples:}

During mating season, blood samples from 7 ewes of each group were collected through vein puncture (using clinical needle) at 0,3, 7, 11, 17 and 20 days, and from day of estrus (day 0) and then at biweekly interval in pregnant ewes up to parturition. Blood samples were centrifuged at $3000 \mathrm{rpm}$ for 20 minutes for the separation of serum and kept at $-20^{\circ} \mathrm{C}$ until further analysis.

Progesterone hormone was measured by ELISA method using IMMUNOSPEC kits supplied by Immunospec Corporation, 7018 Owensmounth Ave. Suite 103 Canoga Park, CA 91303, USA.

\section{Chemical composition of feeding staff:}

Samples from roughage and concentrate mixture were taken monthly to determine their chemical composition according to A.O.A. C. (1990).

\section{Statistical procedure:}

Statistical analysis was performed using least square methods described by Sndecor and Cochran (1980). Significance for mean differences was tested according to Duncan Multiple Range Test (Duncan 1955). The General Linear Methods Procedure of SAS (1998) was employed.

\section{RESULTS AND DISCUSSION}

Results of the chemical analysis of different experimental rations are shown in Table (2). The present results indicated that dry matter, ether extract, nitrogen free extract and ash were nearly similar in all tested rations. While, crude protein was higher in soya bean meal (SBM) followed by NSM compared to cotton seed meal (CSM) with values being 46.5, 31.3 and 24.0 respectively. Ether extract was higher in NSM than CSM and SBM with values being 8.5, 4.0 and 2.2\%, respectively. This indicated that NSM could be considered among the richest protein and energy sources in ruminant diets. These results were in harmony with those reported by El-Nattat and El-Kady (2007), Youssef (2008) and Attia (2015).

\section{Reproductive parameters:}

As shown in Table (3), number of ewes used in mating season was 60 ewes (20 in each group), but 4 of them were barren, one ewe in G1 and G2 and two ewes in G3, while number of stillbirth ewes were 2 in G1 and G3 while one ewe aborted in G2. Data in Table (3) showed that conception rate did not differ significantly between different experimental groups with values being 95, 95 and 90\% for G1, G2 and G3, respectively. These results are in agreement with those reported by El-Harairy et al. (2006) who reported that conception rate was not affected by feeding ration contained NSM as a source of $50 \%$ of CFM protein in Rahmani ewes. Also, lambing rate followed the same trend as conception rate with values being 90,90 and $85 \%$ for G1, G2 and G3, respectively. 
On the other hand, groups supplemented with NSM had improved productive traits; number of lambs born alive were insignificantly increased in G2 and G3 compared to control group (19 and 18 Vs. 17 lambs, respectively). Also, number of lambs weaned showed the same trend (18 and 17 Vs. 15 lambs, respectively) which indicated that NSM can improve lambs survival and performance. Moreover, mortality rate from birth to weaning was higher in control group compared to the other two groups (11.7, 5.2 and $5.5 \%$ for control, G2 and G3, respectively). This result may be due to the positive effects of NSM on the health performance of lambs (Randa, 2007 and Ayoub et al., 2011).

Table (3): Reproductive performance of the different experimental groups.

\begin{tabular}{lccc}
\hline Item & G1 & G2 & G3 \\
\hline No. of ewes joined & 20 & 20 & 20 \\
No. of ewes conceived & 19 & 19 & 18 \\
Conception rate \% & 95 & 95 & 90 \\
No. of ewes lambed & 18 & 18 & 17 \\
Lambing rate \% & 90 & 90 & 85 \\
No. of barren ewes & 1 & 1 & 2 \\
No. of stillbirth & 1 & 0 & 1 \\
No of ewes aborted & 0 & 1 & 0 \\
No. of lambs born alive & 17 & 19 & 18 \\
No. of lamb weaned & 15 & 18 & 17 \\
Weaning rate $\%$ & 88.2 & 94.7 & 94.4 \\
Mortality rate from birth to weaning \% & 11.7 & 5.2 & 5.5 \\
\hline
\end{tabular}

G1; the control concentrate ration (0\% Nigella sativa), G2; 50\% Nigella sativa, G3; 100\% Nigella sativa as a partial replacer of source of protein.

Youssef et al. (1998) reported that NSM significantly improved some reproductive parameters included the number of days open, number of services per conception and calving interval in Egyptian buffaloes. Similar results were reported by El-Gaafrawy et al. (2003) who found that the incidences of drop of fetal membrane after parturition for cows fed 50\% NSM were lower than those for control group while, the interval from calving to complete uterine involution, the interval from calving to first estrus and the interval from calving to conception were significantly shorter in NSM group than that in control group. Also, number of services per conception was significantly decreased in treated cows compared to control group.

The positive effect of NSM on these reproductive parameters may be attributed to the higher content of unsaturated fatty acids palmitic, oleic and linoleic acid originated from Nigella sativa seeds (Al-Gaby, 1992).

\section{Ewes and lambs weight:}

Body weight changes during five months of gestation period of the different experimental groups (Table 4) showed that NSM increased weight gain in ewes after parturition by about $1 \mathrm{~kg}$ in G3 and G2 compared with control group with values being 7.5, 7.4 and $6.7 \mathrm{~kg}$, respectively, indicating better nutritional management during the different physiological stages. Nigella sativa meal rations were able to cover the requirements of ewes without any adverse effects on either feed intake or feed conversion efficiency which reflected on birth weight of their lambs.

This result is in agreement with those reported by Mahmoud and Bendary (2014) who found that final weight and average daily gain did not show significant $(\mathrm{P}<0.05)$ differences, but there was a slight increase in average daily gain and final weight in growing Friesian calves by $125 \mathrm{~g}$ and $15 \mathrm{~kg}$ with ration contained $12.5 \%$ NSM and 12.5 sesame seed meal compared with ration contained soybean meal and cotton seed meal. Also, Abd El-Rahman et al. (2011) reported that growing Demeshgi goats showed highest value of average daily gain when fed ration contained $20 \%$ NSM.

From another point of view, lambs birth weight, weaning weight and average daily gain were significantly $(\mathrm{P}<0.05)$ increased in NSM groups compared to control group indicating better performance of the two NSM groups (Table 5). The higher birth weight of lambs born to ewes fed on NSM might be related to that protein requirements were adequate and rapidly degradable (Chandler, 1993). While, weaning weight and average daily gain were increased due to increase of milk production 
in ewes fed on NSM. Similar results were also reported by Shams El-Dein et al. (2006) who found that birth, weaning weight and average daily gain were significantly increased in Mariz goats fed NSM. On the other hand Gaber et al. (1998) found that there were no significant differences in average daily gain in lambs fed on ration contain 20 or $40 \%$ of NSM.

Table (4): Body weight changes (kg) of the different experimental groups during gestation period

\begin{tabular}{lccc}
\hline Item & $\mathrm{G} 1$ & $\mathrm{G} 2$ & $\mathrm{G} 3$ \\
\hline Initial body weight & 38.9 & 39.5 & 38.5 \\
Weight just before lambing & 52.6 & 53.4 & 52.6 \\
Weight just after lambing & 45.6 & 46.9 & 46.0 \\
Weight gain during pregnancy period & 6.7 & 7.4 & 7.5 \\
\hline G1; the control concentrate ration (0\% Nigella sativa), G2; 50\% Nigella sativa, G3; 100\% Nigella sativa as a partial \\
replacer of source of protein.
\end{tabular}
replacer of source of protein.

Table (5): Some productive traits (mean \pm SE) of the different experimental groups

\begin{tabular}{lccc}
\hline Item & $\mathrm{G} 1$ & $\mathrm{G} 2$ & $\mathrm{G} 3$ \\
\hline $\begin{array}{l}\text { Average birth weight }(\mathrm{kg}) \\
\text { Average weaning weight }(\mathrm{kg})\end{array}$ & $3.01^{\mathrm{b}} \pm 0.10$ & $3.31^{\mathrm{a}} \pm 0.10$ & $3.44^{\mathrm{a}} \pm 0.10$ \\
$\begin{array}{l}\text { Average daily gain from birth to weaning } \\
(\mathrm{g} / \mathrm{h} / \mathrm{d})\end{array}$ & $20.56^{\mathrm{b}} \pm 0.41$ & $21.88^{\mathrm{a}} \pm 0.40$ & $23.00^{\mathrm{a}} \pm 0.42$ \\
\hline $\begin{array}{l}\text { G1; the control concentrate ration (0\% Nigella sativa), G2; 50\% Nigella sativa, G3; 100\% Nigella sativa as a partial } \\
\text { replacer of source of protein. }\end{array}$ & $194.99^{\mathrm{b}} \pm 4.03$ & $206.34^{\mathrm{ab}} \pm 3.91$ & $217.25^{\mathrm{a}} \pm 4.16$ \\
\end{tabular}

\section{Milk yield and composition:}

The milk yield was insignificantly affected by the source of protein (Table 6). Data in Table (6) concluded that total milk yield was insignificantly increased in G3 followed by G2 then control group with values being 630, 606 and $589 \mathrm{ml} / \mathrm{h} / \mathrm{d}$ for G3, G2 and control group, respectively. This result is in agreement with those reported by Shams El-Dein et al., (2006) who reported that daily milk production was significantly increased in Mariz goats fed on NSM in concentrate rations compared with sun flower meal, cotton seed meal and soya bean meal. These results may be due to don't rapidly degradable the source of nitrogen used in the rumen during lactation period (Robinson, 1979).

Concerning Nigella sativa seeds, the increase in milk yield and lactation period may be attributed to the galactogoetic effect of the active component that Nigella sativa seeds may contain (El-Ghousein, 2010). Singh et al. (1993) discovered that the positive effect of galactogogues on milk production may be due to the decrease in circulating biogenic amines such as, histamine, tryptamine and tyramine in blood which are known to cause excessive release of catecholamines in mobile pool leading to suspension of milk secretion as well as causing indigestion by inhibiting the ruminal mobility and absorption.

Naser et al. (2009) found that milk production was improved in milking cows when NSM added by $5 \%$ to concentrate ration. On the other hand, Youssef et al. (1998) found no significant differences in total milk yield between 6 groups of Egyptian buffalos which fed on NSM or basal diet without NSM pre and postpartum periods.

The effect of dietary treatment on ewes milk composition is shown in Table (6). Milk protein, total solids and solids not fat percentages were increased $(\mathrm{P}<0.05)$ in NSM groups, while fat percentage was significantly decreased $(\mathrm{P}<0.05)$ in $\mathrm{G} 3$ compared with other groups. On the other side, milk lactose and ash percentages were not differed. Increase the percentage of protein and low fat content may be due to that milk protein is directly proportional to the amount of milk production, while the percentage of fat is inversely proportional to the amount of milk which produced from ewes Susin et al. (1995). These results are in accordance with those reported by Shams El-Dein et al. (2006) who found that milk protein increased, while milk fat decreased by improving milk production in goats fed on NSM.

\section{Progesterone concentration:}

Progesterone $(\mathrm{P} 4)$ concentration was low in all groups on the day of estrus $(0.25 \pm 0.03,0.24 \pm 0.03$ and $0.21 \pm 0.03 \mathrm{ng} / \mathrm{ml}$ ) for G1, G2 and G3, respectively followed by a gradual increase due to the presence 
of active CL. While, in all groups, plasma P4 level increased with the progress of pregnancy exhibiting higher peak at day $110(4.51 \pm 0.79,3.54 \pm 0.79$ and $4.07 \pm 0.79 \mathrm{ng} / \mathrm{ml}$ for $\mathrm{G} 1, \mathrm{G} 2$ and $\mathrm{G} 3$, respectively) of pregnancy and gradually declined thereafter till parturition (Fig 1). P4 concentration was insignificantly higher in control group than tested groups during experimental period indicated that NSM didn't effect on hormonal profile. These results in agreement those reported by Youssef et al. (1998) who found that no significant effect for NSM or cotton seed meal on P4 concentration in Egyptian buffaloes.

Table (6): Effect of treatment on milk yield and composition of experimental groups

\begin{tabular}{lccc}
\hline Variable & G1 & G2 & G3 \\
\hline Milk yield & $589.3 \pm 29.58$ & $606 \pm 29.58$ & $630 \pm 29.58$ \\
Milk composition (\%) & & & \\
Fat (F) & $3.26^{\mathrm{ab}} \pm 0.30$ & $4.02^{\mathrm{a}} \pm 0.30$ & $2.88^{\mathrm{b}} \pm 0.30$ \\
Protein (P) & $3.09^{\mathrm{b}} \pm 0.09$ & $3.45^{\mathrm{a}} \pm 0.09$ & $3.40^{\mathrm{a}} \pm 0.09$ \\
Lactose (La) & $4.67 \pm 0.16$ & $5.00 \pm 0.16$ & $5.04 \pm 0.16$ \\
Ash & $0.74 \pm 0.01$ & $0.76 \pm 0.01$ & $0.77 \pm 0.01$ \\
Total solids (TS) & $11.77^{\mathrm{b}} \pm 0.38$ & $13.21^{\mathrm{a}} \pm 0.38$ & $12.10^{\mathrm{b}} \pm 0.38$ \\
Solids not fat (SNF) & $8.47^{\mathrm{b}} \pm 0.26$ & $9.19^{\mathrm{ab}} \pm 0.26$ & $9.33^{\mathrm{a}} \pm 0.26$ \\
\hline
\end{tabular}

G1; the control concentrate ration (0\% Nigella sativa), G2; 50\% Nigella sativa, G3; 100\% Nigella sativa as a partial replacer of source of protein.

After parturition, (at day 155) plasma P4 concentration recorded the lowest values $(0.31 \pm 0.04$, $0.30 \pm 0.04$ and $0.29 \pm 0.04 \mathrm{ng} / \mathrm{ml}$ for $\mathrm{G} 1, \mathrm{G} 2$ and G3 respectively). These results of hormonal profile during gestation period agreed with those reported by Abdalla et al. (2007) and Digby et al. (2008).

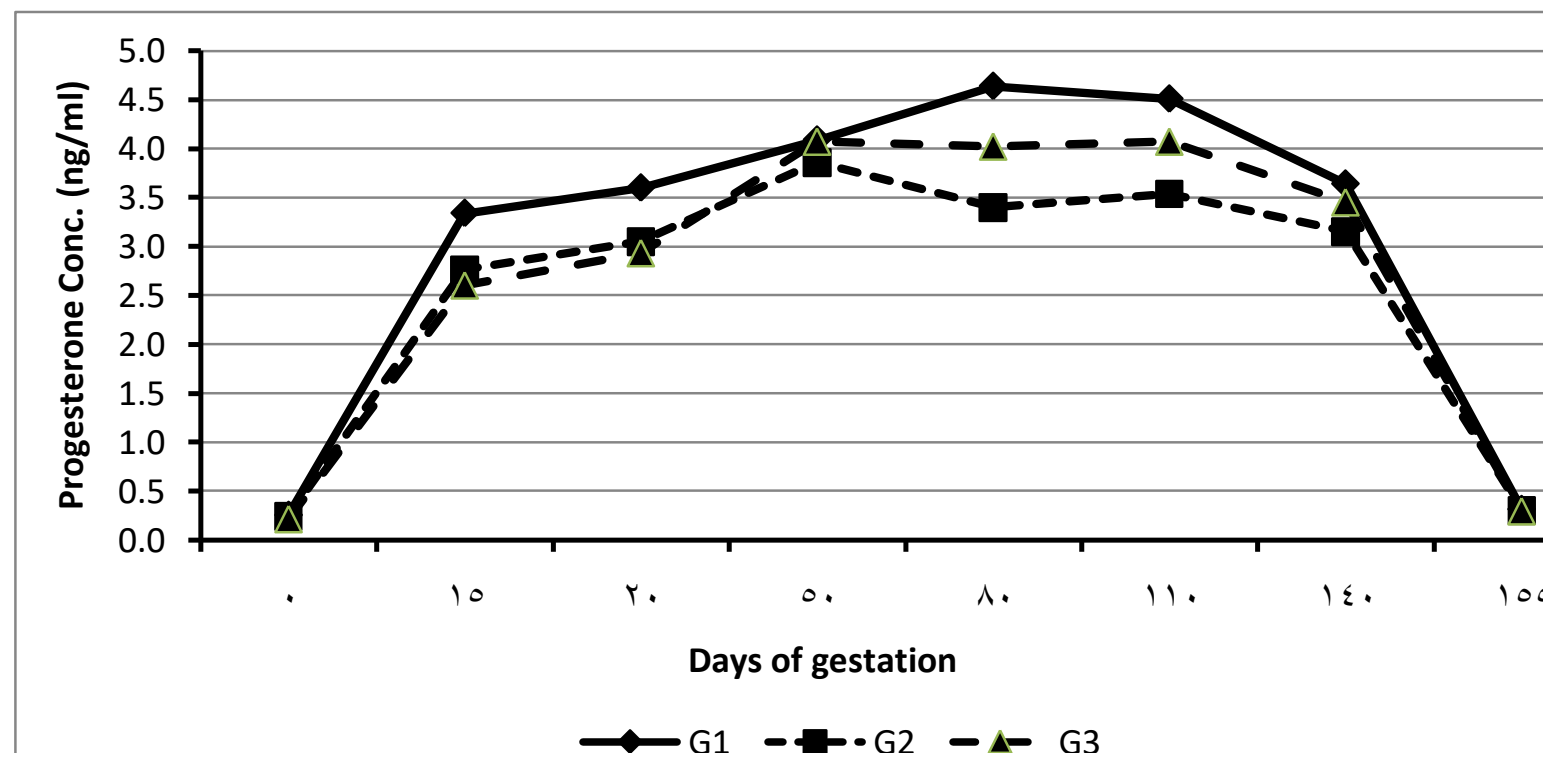

Fig (1). Plasma P4 concentration of the different experimental groups during gestation period

G1; the control concentrate ration (0\% Nigella sativa), G2; 50\% Nigella sativa, G3; 100\% Nigella sativa as a partial replacer of source of protein.

\section{CONCLUSION}

It could be concluded that inclusion of NSM as an alternative source of ration protein in ewes diets may have beneficial effect on reproductive and productive performance of Barki ewes as well as their lambs. 


\section{REFERENCES}

A.O.A.C. (1995). Official Methods of Analysis. Association of official analytical chemists international; 16th Edition, Vol. 1, Ageicultural, chemicals, contaminants Drugs Washington, D.C., U.S.A.

Abd El-Rahman, H.H.; A.A. Abedo; Salman Fatma M.; M.I. Mohamed and M.M. Shoukry (2011). Partial substitution of cumin seed meal by jatropha meal as a potential protein source for feed. African J. of Biotec., 10(68): 15456-15461.

Abdalla, E.B.; H.A. Gawish; A.S. El-Hawy and A.F. Hussin (2007). Reproductive performance of Barki ewes in Siwa Oasis as affected by including date seeds in the concentrate ration, Egypt. Soc. Anim. Reprod. Fert., $19^{\text {th }}$ annual congr Hurgada:277-246.

Al-Gaby, A.M. (1998). Amino acid composition and biological effects of supplementing broad bean and corn proteins with Nigella Sativa (black cumin) cake protein. Nahurng 42(5), 290.

Anwar, U.; H. Gilani; Q. Jabeen and M.A.U. Khan (2004). Immune response and productive performance of dairy buffaloes and their offspring supplemented with black seed oil boil. Pakistan. J. Biol. Sci., 7: 441.

Attia, H.S. (2015). Some physiological and reproductive studies on growing Barki lambs fed Nigalla sativa meal under semi-arid condition. Ph D. Thesis, Fac. of Agric., Al-Azher Univ., Egypt.

Ayoub, M.M.; A.H. El-Far; N.M. Taha; M.A. Korshom; A.A. Mandour; H.S. Abdel-Hamid and M.S. ElNeweshy (2011). The biochemical protective role of some herbs against aflatoxicosis in ducklings: ii. Nigella Sativa. Turmeric, Lucrari Sinţifice-Universitatea de Stiinte Agricole si Medicina Veterinara,Seria Zootehnie, 55: 150-159.

Chandler, P. (1993). Milk protein: a question of content or amount actually produced. Feedstuffs, 14: 1112.

Chevallier, A. (1996). The encyclopedia of medicinal plant. dk publishing, Inc. New York 10016 USA.

Dancun, D.B. (1955). Multiple range and multiple f tests. Biometrics, 11:1-42.

Devegowda, G. (1996). Herbal medicines, an untapped treasure in poultry production in: Proc. $20^{\text {th }}$ World Poult. New Delhi, India.

Digby, S.N.; D.G. Masters; D. Blache; M.A. Blackberry; P.I. Hynd and D.K. Revell (2008). Reproductive capacity of Merino ewes fed a high-salt diet. Anim., 29: 1353-1360.

El-Gaafarawy, A.M.; A.A. Zaki; El-Sedfy Enas, R. and I. El-Ekhnawy (2003). Effect of feeding Nigella Sativa cake on digestibility, nutritive value, reproductive performance of friesian cows and immune activity of their offspring. Egypt. J. Nutr. and Feeds, (special issue) 6:539.

El-Harairy, M.A.; M.G. Gabr; S.A. El-Ayouty; A.A. Gabr and E.S. El-Gohary (2006). Effect of feeding level and replacement of Nigella Sativa meal in dites of rahmani ewe lambs on: 1. growth performance at pre- and post-pubertal ages. Egypt. J. of Sheep, Goat and Desert Anim. Sci., 1(1):153.

El-Nattat, W.S. and R.I. El-Kady (2007). Effect of different medicinal plant seeds residues on the nutritional and reproductive performance of adult male rabbits. International J. of Agric. and Boil., 9(3): 479-485.

Ferdous, A.J.; S.N. Islam; C.M. Ashan and Z.U. Ahmad (1992). In vitro antibacterial activity of the volatile oil of Nigella Sativa seeds against multiple drug-resistant isolates of shigella spp. and isolates of vibrio cholerae and Escherichia coli. Phototherapy Res., 6(3): 137.

Gaber, A.A.; S.A. El Ayouty; A.A. Zaki; Abou Ammo Fatma, F. and E.S.I. El Gohary (1998). Productive performance of lambs fed diets containing Nigella Sativa meal. Egypt. J. Nutr. and Feed, 1(2): 97-102.

Ismaiel, A.M.; A.H. Elfar and I.I. Abou-Gonema (2010). Effect of tonilisat and roemin w2 supplementation on performants of lambs. World Academy of Sci., Engineering and technology, 47: 11-29. 
Kearl, L.C. (1982). Nutrient requirements of ruminants in developing countries. International Feedstuffs Institute, Utah, USA.

Khalil, M.A.; H.B. Sammour and M.A. El-Wardani (2013). Socio-economic and technical evaluation of sheep and goats farms in North West cost of Egypt. Egypt. J. of Sheep and Goats Sci., 8(1): 29- 42.

Mahmoud, A.E.M. and M. M. Bendary (2014). Effect of whole substitution of protein source by Nigella Sativa meal and sesame seed meal in ration on performance of growing lambs and calves. Global Veterinarian 13(3): 391-396.

Mohamed, A.H.; B.E. El-Saidy and I.A. El-Seidy (2003). Influence of some medicinal plants supplementation: 1- on digestibility, nutritive value, rumen fermentation and some blood biochemical parameters in sheep. Egypt. J. of Nutr. and Feeds, 6(2): 139-150.

Nair, S.C.; M.J. Salomi; B. Panikkar and K.R. Painkkar (1991). Modulatory effects of crocus sativus and Nigella Sativa extracts on cisplatin-induced toxicity in mice. J. Ethnopharmacol.; 31(1): 75-83.

Nasser, A.K.; N.M. Abdullah and N.Y. Abou (2011). Using Nigalla sativa meal as substitute source for vegetables protein in rations of native growing calves. Iraqi. J. of Vet. Sci., 25(2): 87-92.

Pluske, J.R. (2013). Feed and feed additives related aspects of gut health and development in weanling pigs. J. of Anim. Sci. and Biotec, 4: 1.

Randa, R.E. (2007). Performances of goats fed certain medical herbs with reference to milk production and its manufacture. Ph.D. Thesis, Fac. of Agric., Cairo Univ., Egypt.

Robinson, J.J.; I. McHattie; J.F. Calderon-Cortes and J.L. Thompson (1979). Further studies on the response of lactating ewes to dietary protein. Anim. Prod., 29: 257.

El-Ghousein, Safaa, S. (2010). Effect of some medicinal plants as feed additives on lactating Awassi ewe performance, milk composition, lamb growth and relevant blood items. Egypt. J. Anim. Prod., 47 (1): $37-49$.

Sanad, M.A. (2000). Productive performance and metabolism in Saidi ewes and their lambs .M.Sc. Thesis, Fac. Of Agric., Assiut Univ., Egypt.

SAS, (1998). User's guide: Statitical Analysis System Ver 9.1.3. SAS Institute. Cary, NC, USA.

Shams El-Dein, K.Z.; Abdel-Hamied Alham, M.; N.H. Kader and A.H. Abdallah (2006). Using different sources of feeds in pregnant maiz Almariz does rations and their effect on growth of kids, milk yield and composition. Al- Taqani., 19(3): 87-93.

Singh, N.; M.A. Akbar and M.R. Kumari (1993). Effect of some commonly used galactagogues on different blood biochemical constituents of lactating buffaloes. Indian Vet. Med. J., 70: 441.

Snedecor, G.W. and W.G. Cochran (1980). Statistical methods. $7^{\text {th }}$ edition, Iowa State University Press, Ames, Iowa.

Susin, I. (1995). Effects of feeding a high-grain diet at a restricted intake on lactation performance and rebreeding of ewes. J. Anim Sci., 73(11): 199-205.

Tsedeke, K. (2007). Production and marketing of sheep and goats in Alaba, Southern Ethiopia. M.Sc. Thesis, Hawassa. Ethiopia.

Youssef, M.M.; A.M. Abdliene; R.M. Khattab and S.A. Darwish (1998). Effect of feeding Nigella Sativa cake on productive and reproductive performance of buffaloes. Egypt. J. Nutr. and Feed, 1(2): 73.

Zanouny, A.I.; A.K.I. Abd-Elmoty; M.A.A. El-Barody; M.T. Sallam and A.A. Abd El- Hakeam (2013). Effect of supplementation with Nigella Sativa seeds on some blood metabolites and reproductive performance of Ossimi male lambs. Egypt. J. of Sheep and Goat Sci, 8(1): 47-56. 
الكفاءة التناسلية والإنتاجية للنعاج البرقي المغذاة علي كسب حبة البركة كمصدر لبروتين العليقة

\author{
عصمت بكري عبد اللها, احمد صبحي الحاوي², حمدي عبد العزيز جاويش² و عفت مراد مدني2

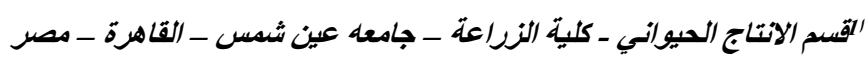

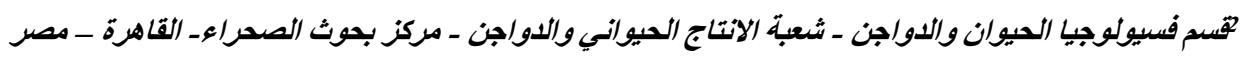

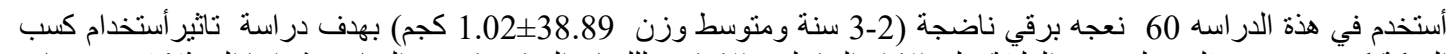

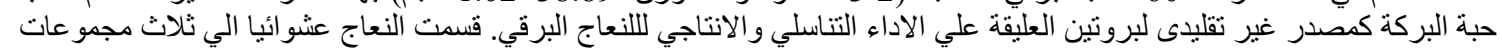

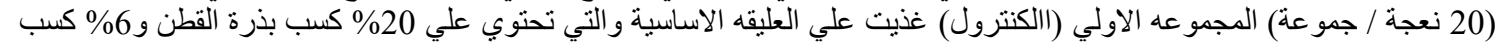

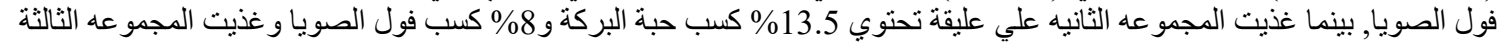

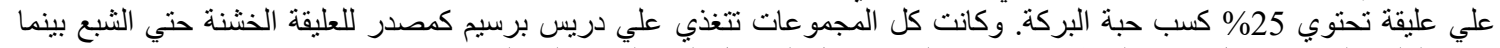

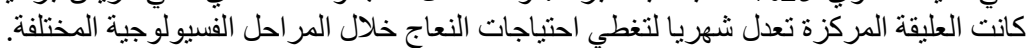

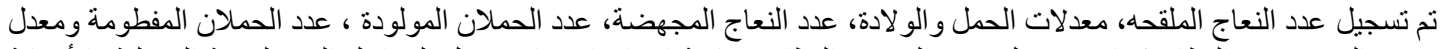

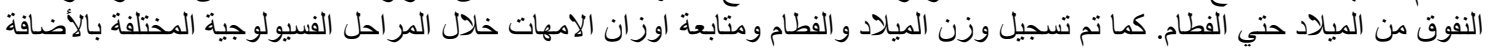
الي تقدير أنتاج اللبن وتنركيية.

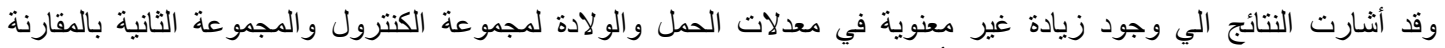

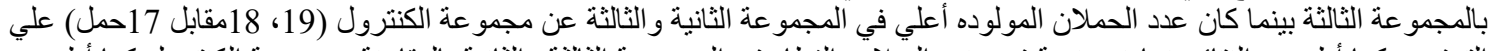

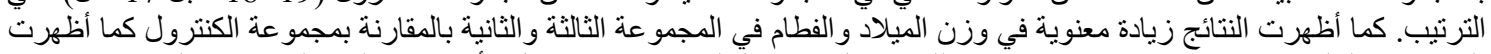

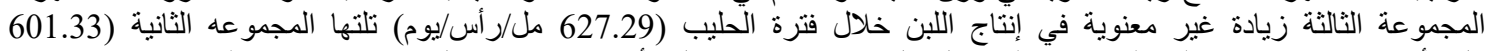

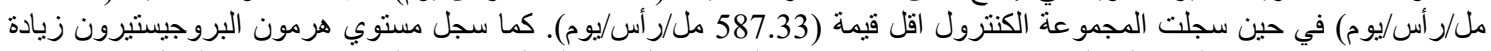

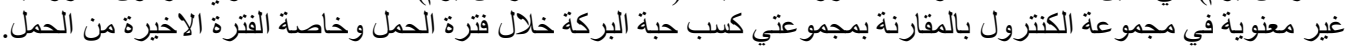

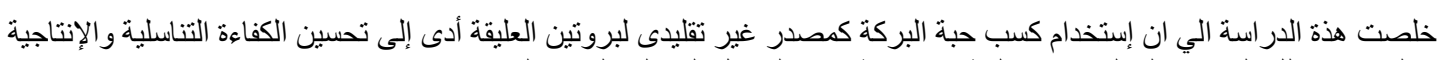

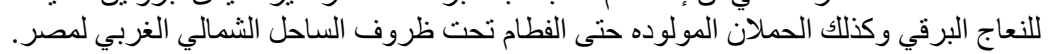

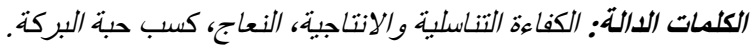

